\title{
DAISY CONTROL AND PASTURE TOLERANCE
}

\author{
R.B. MITCHELL and R.J. ABERNETHY \\ Invermay Agricultural Centre, Private Bag, Mosgiel
}

\section{SUMMARY}

Paraquat, paraquat/diquat and diquat with or without added 2,4-D amine or 2,4-D ester consistently reduced daisy (Bellis perennis) populations in pastures by over $80 \%$. Nitrogen in the form of sulphate of ammonia applied post-spraying assisted the recovery of the grasses which were damaged by the herbicides. Clover was more tolerant to paraquat and paraquat/diquat than to diquat alone. 2,4-D amine significantly reduced clover DM production when added to paraquat or diquat.

\section{INTRODUCTION}

Daisy is a prostrate perennial weed present in most pastures in lowland Otago and Southland where it may reduce pasture production. For example, Meeklah and Mitchell (1985) reported that a daisy cover of $28 \%$ in a pasture yielding $8,500 \mathrm{~kg} \mathrm{DM} / \mathrm{ha}$, reduced total season DM by $500 \mathrm{~kg} / \mathrm{ha}$.

Daisy control methods using herbicides were reported by Meeklah et al (1981) and Mitchell and Meeklah (1986). In these studies reductions in daisy cover were recorded but in some trials the more effective herbicides caused severe damage to the clovers. This paper reports the results of two trials where paraquat and diquat plus 2,4-D and nitrogen were evaluated. The effects of the treatments on daisy populations were recorded as were changes in the clover content of the swards.

\section{MATERIALS AND METHODS}

Two trials were carried out, each consisting of treatments within four fully randomized blocks. Plot size was $10 \mathrm{~m}$ or $15 \mathrm{~m} \times 1.5 \mathrm{~m}$. Herbicides were applied with a modified Oxford Precision sprayer using 8002 fan nozzles delivering 250 litres/ha of water to ryegrass/clover pastures 3-8 cm high. Paraquat (Gramoxone) and diquat (Reglone) were applied at $0.2 \mathrm{~kg} / \mathrm{ha}$, paraquat/diquat (Spraygrow) at $0.2 / 0.3 \mathrm{~kg} / \mathrm{ha}$ and two 2,4-D formulations (Weedar 77 and Hi-ester 2,4-D) at $1 \mathrm{~kg} / \mathrm{ha}$. Sulphate of ammonia as a source of nitrogen was applied by hand to the plots treated with herbicide. Percentage cover of daisy and clover was dc 'ermined by point analysis in Trial 1, taking 100 points per plot, while dry matter production was measured in Trial 2.

Trial 1: Herbicide treatments (Table 1) were applied in either early October or late November 1984 to a pasture with $16 \%$ cover of daisies. Nitrogen at $84 \mathrm{~kg} / \mathrm{ha}$ was applied to half of each sprayed plot within 1 week after spraying. Clover cover was recorded in April 1985 and daisy cover in October 1985.

Trial 2: Herbicides (Table 2) were applied on 11-11-86 to plots averaging $12 \%$ daisy cover. On 19-11-86 N was applied at $42 \mathrm{~kg} / \mathrm{ha}$ as a single application and $1 \mathrm{~m}^{2}$ exclusion cages were placed on each sprayed plot to prevent grazing. Herbage cuts from the total area of each cage were taken with a shearing hand-piece five times between 7-12-86 and 9-5-87 with a further cut on 28-10-87. The cages were then removed over summer and were replaced on each plot on 18-2-88. A final cut was taken on 28-3-88.

\section{RESULTS}

Trial 1: By October 1985 all herbicide treatments, except 2,4-D ester and paraquat/diquat applied in October 1984, had significantly $(P<0.05)$ reduced daisy cover (Table 1). Average cover was $3 \%$ in treated plots compared to $10 \%$ cover in untreated control. Over all treatments the addition of $\mathrm{N}$ improved the control of the daisies irrespective of time of application.

Proc. 43rd N.Z. Weed and Pest Control Conf. 1990: 237-239 
TABLE 1: Effect of herbicide and sulphate of ammonia $(\mathrm{N})$ on percentage clover cover (12.4.85) and percentage daisy cover $(\mathbf{2 . 1 0 . 8 5})$ in Trial 1.

\begin{tabular}{|c|c|c|c|c|c|c|c|c|}
\hline \multirow{4}{*}{ Treatments } & \multicolumn{8}{|c|}{ Date of herbicide application } \\
\hline & \multicolumn{4}{|c|}{ Early (17.10.84) } & \multicolumn{4}{|c|}{ Late $(27.11 .84)$} \\
\hline & \multicolumn{2}{|c|}{ Clover } & \multicolumn{2}{|c|}{ Daisy } & \multicolumn{2}{|c|}{ Clover } & \multicolumn{2}{|c|}{ Daisy } \\
\hline & $-\mathbf{N}$ & $+\mathrm{N}$ & $-\mathbf{N}$ & $+\mathrm{N}$ & $-\mathbf{N}$ & $+\mathbf{N}$ & $-\mathbf{N}$ & $+\mathbf{N}$ \\
\hline paraquat & 33 & 19 & 1.75 & 1.25 & 43 & 26 & 2.75 & 1.5 \\
\hline $2,4-\mathrm{D}$ ester & 20 & 19 & 8 & 3.75 & 29 & 9 & 4.25 & 1.5 \\
\hline paraquat $+2,4-\mathrm{D}$ ester & 35 & 33 & 5 & 0.75 & 47 & 34 & 2 & 1.25 \\
\hline paraquat/diquat & 40 & 29 & 8.25 & 3.25 & 55 & 36 & 3.5 & 2.75 \\
\hline $\begin{array}{l}\text { paraquat/diquat }+ \\
2,4-D \text { ester }\end{array}$ & 37 & 31 & 6 & 2.75 & 55 & 41 & 4 & 1.25 \\
\hline diquat $+2,4-\mathrm{D}$ ester & 27 & 16 & 2.75 & 1.0 & 26 & 11 & 3.25 & 1.5 \\
\hline $\begin{array}{l}\text { paraquat }+ \\
2,4-\mathrm{D} \text { amine }\end{array}$ & 27 & 16 & 2.5 & 0.5 & 29 & 17 & 2.75 & 2.5 \\
\hline untreated control & \multicolumn{2}{|c|}{32} & \multicolumn{2}{|c|}{10.25} & \multicolumn{2}{|c|}{32} & \multicolumn{2}{|c|}{10.25} \\
\hline
\end{tabular}

LSD $(\mathrm{P}<0.05)$ clover -6 herbicide comparison with control $-7 \pm \mathrm{N}$ comparisons -8 columns

daisy -3.0 herbicide comparisons with control $-4.6 \pm \mathrm{N}$ comparisons -3.9 columns

Paraquat/diquat alone and with added 2,4-D ester and paraquat plus 2,4-D ester did the least damage to clover (Table 1). In the absence of $N$ clover cover in sprayed plots was similar to that in the unsprayed control 6 months after spraying (Table 1). However, percentage cover of clover was reduced where $\mathbf{N}$ was applied after most herbicides.

Trial 2: Total daisy DM yield was reduced from $44 \mathrm{~kg} / \mathrm{ha}$ (untreated) to below 6 $\mathrm{kg} / \mathrm{ha}$ by each herbicide over the five cuts taken in the season following spraying (Table 2). Significant yield reductions remained in the three paraquat and in the paraquat/diquat plus either of the 2,4-D formulations at the final cut 28-3-88 taken 16 months after spraying. At this date, these treatments averaged $5 \mathrm{~kg} / \mathrm{ha} \mathrm{DM}$ compared to $25 \mathrm{~kg} / \mathrm{ha} \mathrm{DM}$ in the untreated plots.

TABLE 2: Herbicide effect on grass, clover (tonnes/ha) and daisy (kg/ha) DM yields (Trial 2).

\begin{tabular}{|c|c|c|c|c|c|c|c|c|c|}
\hline \multirow{2}{*}{$\begin{array}{l}\text { Treatments } \\
\text { Applied } 11.11 .86 \\
\text { paraquat }\end{array}$} & \multicolumn{3}{|c|}{$\begin{array}{c}1986-875 \text { cuts } \\
\text { Grass Clover Daisy }\end{array}$} & \multicolumn{3}{|c|}{$\begin{array}{c}28.10 .871 \text { cut } \\
\text { Grass Clover Daisy }\end{array}$} & \multicolumn{3}{|c|}{$\begin{array}{c}28.3 .881 \text { cut } \\
\text { Grass Clover Daisy }\end{array}$} \\
\hline & 5.1 & 1.1 & 5 & 3.0 & 0.2 & 0 & 1.3 & 0.5 & 5 \\
\hline$+2,4-\mathrm{D}$ amine & 5.1 & 0.5 & 1 & 2.7 & 0.1 & 0 & 1.4 & 0.3 & 6 \\
\hline$+2,4$-D ester & 4.1 & 0.8 & 3 & 2.4 & 0.2 & 0 & 1.2 & 0.4 & 5 \\
\hline paraquat/diquat & 4.2 & 1.1 & 1 & 2.8 & 0.3 & 0 & 1.2 & 0.4 & 16 \\
\hline$+2,4-\mathrm{D}$ amine & 4.8 & 0.4 & 1 & 3.0 & 0.2 & 0 & 1.5 & 0.5 & 3 \\
\hline$+2,4-\mathrm{D}$ ester & 4.3 & 1.0 & 5 & 2.6 & 0.2 & 0 & 1.3 & 0.5 & 5 \\
\hline diquat & 5.8 & 0.4 & 1 & 2.0 & 0.2 & 6 & 1.3 & 0.3 & 9 \\
\hline$+2,4-\mathrm{D}$ amine & 5.6 & 0.4 & 2 & 2.8 & 0.1 & 5 & 1.2 & 0.4 & 9 \\
\hline$+2,4-\mathrm{D}$ ester & 5.7 & 0.4 & 6 & 2.6 & 0.2 & 2 & 1.5 & 0.4 & 8 \\
\hline untreated & 5.3 & 0.9 & 45 & 2.4 & 0.2 & 6 & 1.1 & 0.4 & 25 \\
\hline LSD 5\% & 1.4 & $\begin{array}{l}0.6 \\
1.7^{1}\end{array}$ & 14 & 0.4 & $\begin{array}{l}0.1 \\
0.4\end{array}$ & 5 & 0.3 & $\begin{array}{l}0.2 \\
0.3\end{array}$ & 18 \\
\hline
\end{tabular}

${ }^{1}$ LSD $5 \%$ for the combined grass/clover yield 
In the season following spraying (to 9-5-87) the combined DM yield for grass and clover did not differ either between herbicide treatments or between any herbicide treatment and untreated control (Table 2). There were significant differences in grass and clover yields when comparing individual treatment effects. Diquat severely affected clover production whether applied alone or in combination with either 2,4-D formulation. The addition of 2,4-D amine to either paraquat or paraquat/diquat resulted in significantly reduced clover DM yields.

Some significant effects remained at the 28-10-87 cut (Table 2), but differences had largely disappeared by the final harvest 28-3-88.

\section{DISCUSSION}

Results from these and previously reported trials have shown that paraquat, paraquat/diquat and diquat consistently reduced daisy cover in grazing pasture by over $80 \%$. The addition of 2,4-D amine or 2,4-D ester to these materials did not significantly improve each herbicide's performance and can cause severe clover damage. Nitrogen assisted pasture recovery by increasing grass growth but rates above $42 \mathrm{~kg} / \mathrm{ha}$ seriously suppressed clover recovery. In a similar trial not reported here, the response to nitrogen was the same whether applied as a single or split application. A further trial, also unreported, showed pasture recovery could be seriously delayed by dry conditions after spraying. The greater effect on clover of diquat alone, compared with that of either paraquat or paraquat/diquat, reflects the activity of diquat on broadleafed plants and the rates at which it was applied $(0.2 \mathrm{~kg} / \mathrm{ha}$ on its own and at $0.03 \mathrm{~kg} / \mathrm{ha}$ when in combination with paraquat).

Our trials have all been conducted on properties where fat lambs and wool are the farmer's main source of income. Lambs fatten more rapidly on clover dominant pasture (Lewis 1956; Jagusch et al 1981) and maximum live weight gains are not possible if clover growth is suppressed or eliminated in a ryegrass clover sward. Paraquat and paraquat/diquat are commonly used for grass suppression in grazing pastures and the recommended timing for this approach fits into the period in which we have achieved the best daisy control.

From earlier trial work daisy infestations do not appear to reduce pasture production until they occupy over $30 \%$ of available ground cover (Meeklah and Mitchell 1985). Where daisies are considered to be a problem in pasture, the application of paraquat or paraquat/diquat at the rates used here, will provide worthwhile control. Nitrogen applied after spraying will help maintain pasture production but in dry conditions recovery can be seriously delayed. Diquat should only be used if pasture damage to resident clovers is considered unimportant.

\section{ACKNOWLEDGEMENTS}

To Messrs C. Davis and C. Batchelor for trial sites and the biometrics staff at Invermay.

\section{REFERENCES}

Jagusch, K.T., Duganzich, D.M., Winn, G.W. and Rattray, P.V., 1981. The effect of season of the year and pasture allowance on the growth of lambs fed different pasture species. Proc. 4lst N.Z. Soc. Animal Prod.: 117-118.

Lewis, K.H.C., 1956. The use of weed killers in relation to fat lamb production. Proc. 9th N.Z. Weed and Pest Control Conf.: 101-105.

Meeklah, F.A., Mitchell, R.B. and McMillan, H., 1981. Chemical control of daisies in Otago/Southland pastures. Proc. 34th N.Z. Weed and Pest Control Conf.: 137-140.

Meeklah, F.A. and Mitchell, R.B., 1985. Effect of daisy removal on pasture production. Proc. 38th N.Z. Weed and Pest Society Conf.: 119-121.

Mitchell, R.B. and Meeklah, F.A., 1986. Daisy control in pastures using herbicides and nitrogenous fertilisers. Proc. 39th N.Z. Weed and Pest Control Conf.: 192-195. 